\title{
Analisis Komparasi Strategi Pemasaran dalam Transaksi Jual Beli Online dan Offline pada Hijab (Studi Kasus: Mahasiswi Universitas Islam Riau)
}

\author{
Zulfadli Hamzah', Muhammad Arif ${ }^{2}$ \& Chairun Nisa ${ }^{3 *}$ \\ * Fakultas Agama Islam (FAI) Universitas Islam Riau (UIR) Pekanbaru \\ Jl. Kaharuddin Nasution No.113 Perhentian marpoyan Pekanbaru, 28284 \\ Email : zulfadlihamzah@fis.uir.c.id, muhammadarif@fis.uir.ac.id, \\ chairunnisa165@gmail.com
}

\begin{abstract}
Abstrak: Penelitian ini dilatarbelakangi semakin berkembangnya sistem teknologi informasi yang berimbas pada perkembangan pemasaran yakni memanfaatkan teknologi informasi dalam melakukan transaksi pembelian secara online. Pembelian secara online merupakan salah satu alternatif yang dipilih karena alasan kemudahan, cepat dan praktis. Selain itu, tidak sedikit juga konsumen memilih pembelian secara offline dengan alasan kepercayaan dan keamanan. Salah satunya dalam produk hijab. Ada kemudahan dalam pembelian hijab secara online namun barang yang dipesan tidak sesuai dengan visualisasi gambar. Sementara dalam pembelian hijab secara offline barang yang diinginkan bisa diketahui spesifikasinya namun jangkaun lokasi dan biaya menjadi hambatan bagi konsumen. Untuk itu, penulis tertarik untuk meneliti analisis komparasi strategi pemasaran dalam transaksi jual beli online dan offline pada hijab (studi kasus: Mahasiswi Universitas Islam Riau) berdasarkan faktor produk, harga, promo, tempat, orang, proses dan bukti fisik. Tujuan dari penelitian ini adalah untuk mengetahui apakah terdapat perbedaan strategi pemasaran dalam transaksi jual beli online dan offline pada hijab (studi kasus: Mahasiswi Universitas Islam Riau). Subjek dalam penelitian ini adalah Mahasiswi Universitas Islam Riau. Sedangkan objek dari penelitian ini adalah strategi pemasaran dalam transaksi jual beli online dan offline pada hijab. Sumber data yang digunakan dalam penelitian ini adalah sumber data primer dan sekunder. Teknik pengambilan sampel adalah menggunakan rumus Slovin, sedangkan teknik pengumpulan data yang digunakan ialah menggunakan angket. Jenis penelitian ini merupakan komparatif dimana proses perhitungannya menggunakan SPSS For Windows versi 23.0 dengan uji analisis paired sample t-test (Uji t dua sampel berpasangan). Sampel penelitian ini sebanyak 99 orang. Berdasarkan hasil uji Perbandingan (Paired T-test) diketahui nilai signifikansi sebesar 0,008 $<0,05$ (nilai probabilitas). Dan berdasarkan nilai $-t_{\text {hitung }}<-$ ttabel yaitu $-2,692<-0.196$, maka ini membuktikan terdapat perbedaan strategi pemasaran dalam jual beli online dan offline pada hijab (Mahasiswi Universitas Islam Riau).
\end{abstract}

Kata Kunci : Strategi Pemasaran, Jual-beli, Online, Offline, Hijab 


\section{PENDAHULUAN}

Islam adalah agama yang universal (syamil) dan seimbang (tawazun). Keuniversalan Islam tampak pada aturanaturan yang Allah ciptakan itu berlaku untuk umat manusia dan alam semesta. Aturan-Nya meliputi seluruh aspek dan menyeluruh dibidang hukum (syari'at), ekonomi (muamalah), sosial (akhlak) dan lainnya. Allah menciptakan aturan dalam bidang ekonomi seperti bagaimana bermuamalah terhadap sesama manusia dengan cara memberikan kebebasan kepada manusia dalam meraih rezeki, melalui suatu usaha yang halal dan tentunya ada aturan allah yang tidak boleh dilanggar, seperti terlalu sibuk mencari harta dan cinta dunia sehingga melupakan akhirat. Tujuan dari pemenuhan kebutuhan dalam Islam untuk mencapai maslahah, yaitu pemenuhan kebutuhan manusia dalam rangka menjaga dan memelihara kehidupan, harta, keimanan, akal dan keturunan (Arif dan et.al, 2010:62.

Dalam bermuamalah kita biasanya melakukan transaksi jual beli untuk memenuhi kebutuhan, baik kebutuhan primer (dharuriyat), sekunder (hajiyat), dan tersier (tahsiniyat). Salah satu kebutuhan sandang adalah yang dipakai. Pakaian menjadi kebutuhan pokok bagi manusia dan menjadi ciri khas, identitas dan kepribadian seseorang yang membedakan dari yang lain. Seorang gadis muslimah yang berpakaian menutup auratnya maka sebenarnya dia telah menunjukkan bahwa dirinya sebagai seorang muslimah. Hijab tersebut menjadi pembeda dari yang lain.

Sekarang ini maraknya kaum perempuan khususnya kalangan dewasa yang menggunakan tren hijab sebagai fashion muslimah. Hijab seolah menjadi tren terutama kalangan anak muda, selain fungsi utamanya menutup aurat hijab.
Tentu saja dengan banyaknya pengguna hijab maka permintaan hijab juga semakin banyak. Bahkan untuk satu orang perempuan memiliki hijab satu buah saja tidak cukup, mereka memiliki banyak sekali hijab mulai dari warna, model, dan sebagainya. Tidak dapat dipungkiri, tingginya kebutuhan hijab ini menjadikan permintaan pasar untuk produk hijab meningkat. Sehingga tidak heran jika kini banyak pelaku bisnis yang menjual hijab sebagai bisnis utamanya. Agar bisnis hijab dapat bersaing, berkembang dan mendapatkan keuntungan yang terus meningkat maka penjual harus memiliki strategi pemasaran yang tepat. Salah satunya menerapkan strategi pemasaran marketing mix (bauran pemasaran) yang terdiri dari produk, harga, promosi, distribusi, orang, proses dan bukti fisik.

Berkaitan dengan produk, produsen dituntut bertransformasi secara kreatif dan inovatif dari gaya konservatif menjadi lebih kekinian yang berjiwa muda dalam mendesain model hijab muslimah agar sesuai dengan harapan konsumen, namun tetap memperhatikan fungsi dasar hijab sebagai penutup aurat. Sekarang konsumen semakin bijak sehingga penting menetapkan harga yang kompetitif. Akan lebih baik jika menjual hijab dengan kualitas mumpuni namun bisa menekan harga, atau menetapkan harga sesuai dengan kualitas hijab tersebut.

Ditambah lagi dengan adanya perkembangan bisnis digital atau pemasaran online maka penjual berinovasi dengan memasarkan produk hijab kepada konsumen melalui smartphone (ponsel cerdas) berbasis internet yang mana salah satu fungsinya mereka manfaatkan untuk bertransaksi secara online. Seiring perkembangan teknologi sekarang media sosial sudah menjadi kebutuhan masyarakat karena keterbatasan waktu dan 
tempat. Media sosialpun digunakan konsumen salah satunya sebagai media bertransaksi dalam pembelian hijab. Hal ini karena pembelian melalui media sosial lebih sederhana, mudah, cepat dan praktis.

Jual beli online merupakan penjualan yang diketahui produknya, model, jenis, ukuran, bahan yang nampak dari visualisasi gambar. Namun tidak secara fisik melihat kondisi barang tersebut. Penawaran barang melalui dunia maya, tidak terlihat secara kasad mata, namun calon pembeli sudah bisa memprakirakan atau memiliki bayangan seperti apa barang tersebut, serta memprakirakan kemungkinan cocok atau tidaknya. Tentunya dalam hal ini, peran dari penjual sangat penting untuk meyakinkan calon konsumen atas produk yang ditawarkan mengenai spesifikasi (bahan, ukuran, warna, jenis) barang termasuk harga.

Dalam menentukan pilihan (model, ukuran, warna dan harga), maka untuk mendapatkan busana tersebut pembeli harus melakukan pembayaran secara transfer. Setelah uang tersebut diterima oleh penjual, maka barang segera dikirim ke pembeli sesuai dengan ketentuan waktu pengiriman, ada yang 3-4 hari, 4-5 hari bahkan ada yang seminggu bertujuan efisiensi ongkos kirim.

Lain halnya dengan pembelian secara langsung (offline). Pembelian di toko kita bisa langsung melihat jenis barang, mengetahui spesifikasi dan harganya serta bisa langsung bernegosiasi dan memutuskan untuk membeli atau tidak. Bagi beberapa konsumen, lokasi toko menjadi pertimbangan karena alasan efisiensi waktu, biaya dan tenaga. beberapa konsumen akan memilih toko yang mudah di jangkau dengan keragaman produk yang serta ketersediaan barang.
Selain kualitas produk dan harga, yang menjadi hal penting bagi penjual adalah strategi dalam memutuskan tempat, media dan bentuk promosi, orang mencakup kemampuan dan pelayanan yang diberikan, proses yang mudah dan cepat, dan bukti fisik sehingga mampu meyakinkan konsumen.

Universitas Islam Riau merupakan salah satu Universitas swasta di Riau yang memiliki mayoritas mahasiswi beragama Islam. Berdasarkan prariset yang dilakukan peneliti di 5 Fakultas (Fakultas Agama Islam, Fakultas Hukum, Fakultas Keguruan dan Ilmu Pendidikan, Fakultas Ilmu Sosial dan Politik dan Fakultas Ekonomi) dengan sampel berjumlah 40 mahasiswi didapati fenomena bahwa 75\% (30 mahasiswi) pernah melakukan pembelian hijab secara online. Hal tersebut menunjukkan banyaknya yang melakukan transaksi pembelian hijab secara online. Seiring tingginya minat konsumen tersebut peneliti menemukan keluhan konsumen seperti pengiriman yang lama, barang (bahan dan ukuran) yang dipesan tidak sesuai yang diterima, barang tidak sesuai dengan yang di gambar, rendahnya kualitas barang, masalah ketersedian dan lainnya. Untuk itu perlu bagi penjual menerapkan dan mengembangkan strategi pemasaran (bauran pemasaran) guna memikat konsumen terkait produk, harga, promosi, tempat, orang, dan bukti fisik.

\section{TINJUAN PUSTAKA}

\section{Konsep Strategi Pemasaran}

Lanskap pemasaran beranggapan bahwa dalam mennggapai target perusahaan dimulai dari identifikasi apa yang menjadi kebutuhan dan harapan konsumen, mampu mengidentifikasi pasar sasaran, mengelolanya secara konsisten dan terus menerus serta memperbaharui ide-ide yang disesuaikan kebutuhan dan 
budaya masyarakat setempat. Empat pilar dalam lanskap pemasaran terdiri pasar sasaran, kebutuhan konsumen, pemasaran yang terintegrasi dan profitabilitas. (Huda dan et.al, 2017:5).

Strategi pemasaran oleh Tull dan Kahle (1990) adalah hal yang mendasar, pokok, dan penting dirumuskan untuk mencapai tujuan bisnis dengan pengembangan keunggulan bisnis, berkesinambungan, dan terus memperbaiki kinerja serta memperbarui program pemasaran yang digunakan. Salah satu strategi (program) pemasaran yang digunakan adalah bauran pemasaran (marketing mix) yang terdiri produk, distribusi, promosi, dan harga, orang/karyawan, prosesnya serta bukti fisik atau diistilahkan dengan $7 \mathrm{P}$.

Dalam strategi pemasaran ada lima hal yang saling terkait yaitu penetapan pangsa pasar, rumusan produk, menetapkan harga, sistem dan saluran distribusi yang tepat dan efisien, dan komunikasi pemasaran (promosi) yang kreatif, proses yang mudah dan cepat, karyawan yang ramah dan handal, serta bukti fisik yang meyakinkan konsumen.

\section{Strategi Pemasaran Bauran Pemasaran (Marketing Mix)}

a. Produk

Produk adalah barang, ide, gagasan, jasa yang ditawarkan kepada calon konsumen, memiliki nilai dan manfaat guna memenuhi kebutuhannya. Produk yang baik memiliki fungsi inti, diluar ekspektasi konsumen, ada nilai tambah, dan memiliki potensi. Dalam merancang produk bagaimana produk tersebut selain memiliki nilai gunanya juga menawarkan kelebihan lain yang menjadi pembeda dari produk lain (unik) (Huda dan et.al, 2017:17).

Konsep produk meliputi kinerja, keragaman produk, keistimewaan produk, keandalan, kesesuaian dengan spesifikasi, estetika dan kualitas yang dipersepsikan. Dengan memperhatikan konsep tersebut dalam pengembangannya dilakukan secara konsisten maka produk akan mampu bersaing (Tjiptono, 2008: 25).

Dalam pemasaran syariah, kualitas yang baik tidak boleh bersatu dengan kualitas yang rendah dengan tujuan menyembunyikan aib barang kecuali dijelaskan, serta memperhatikan ukhuwah Islamiyyah (Agustin, 2017:98). Ini merupakan penyebab keberkahan dalam jual beli sebagai mana dalam hadits berikut :

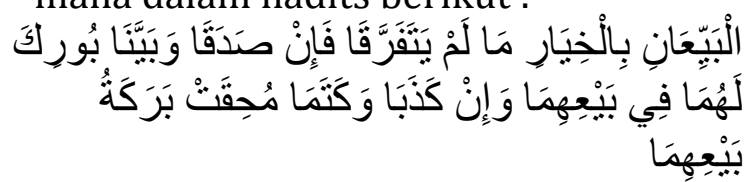

Artinya :"Jika penjual dan pembeli jujur serta menjelaskan cacat barang niscaya akad jual-beli mereka diberkahi. Namun, jika keduanya berdusta serta menyembunyikan cacat barang niscaya dihapus keberkahan dari akad jualbeli mereka" (HR Bukhari dan Muslim)

b. Harga (Price)

Harga merupakan salah satu pertimbangan dalam strategi pemasaran. Harga adalah nilai atau biaya yang dikeluarkan untuk mendapatkan barang atau jasa. Ada 3 jenis harga dalam strategi pemasaran yaitu harga yang terjangkau, harga sebanding dengan kualitas barang, dan pertimbangan harga yang ditetapkan apakah sama atau lebih dari mitranya (Kotler dan Amstrong, 2008: 345).

Dalam menetukan harga perlu dipikirkan seberapa pentingkah harga 
bagi konsumen dan bagaimnana efek dari berubahnya harga terhadap perilaku pembelian konsumen (Setiadi, 2013:9).

Menentuan harga tidak boleh mendzalimi mitra bisnis lainnya. Memang dalam berbisnis tidak dipungkiri kita mengambil keuntungan, namun dalam menetapkan harga hendaknya tidak terlalu tinggi. Lebih baik dengan harga terjangkau namun besar tingkat penjualannya (kuantitas). Daripada harga tinggi tapi sedikit volume penjualannya (kuantitas). Semakin banyak banyak barang terjual maka semakin banyak keuntungannya, maka nyatalah keberkahan rezekinya. Rasulullah menganjurkan agar menetapkan harga sesuai dengan kualitasnya. Rasulullah menjual produk dengan harga yang diserap oleh pasar (Agustin, 2017:99).

c. Promosi (Promotion)

Promosi adalah salah satu elemen bauran pemasaran untuk memberitahukan, mengajak, mendorong dan mengingatkan konsumen bahwa ada barang yang ditawarkan perusahaan. Alat-alat promosi adalah sebagai berikut (Lupiyodi dan A. Hamdani, 2008: 82) adalah periklanan, penjualan perorangan (personal selling), publisitas, informasi dari mulut ke mulut (word of mouth), surat langsung, promosi penjualan. Hendaknya yang perlu dipahami setiap perusahaan bahwa dalam menentukan alat promosi haruslah tepat dan sesuai dengan sasaran agar tercapai tujuan dari promosi tersebut (Huda dan et.al, 2017:17).

Yang perlu diperhatikan dalam promosi haruslah mengandung kebenaran (transparan), periklanan media cetak dan media sosial. Periklanan eletronik (media sosial) adalah bentuk komunikasi dengan cara mengembangkan pesan yang disampaikan: terkait dengan siapa segmen pasar (identifikasi audiens), konteks pesan, struktur pesan, tata bahasa yang logis dan menarik, desain grafis produk yang ditawarkan (menarik), kejelasan produk (jenis, bahan, ukuran, spesifikasi). Bentuk promosi lainnya adanya potongan harga, efisien biaya pengiriman, dan pemberian souvenir secara free.

Adanya istilah ongkos kirim karena pembelian dilakukan terpisah oleh jarak dan waktu. Setelah terjadinya proses pemesanan maka pembeli dikenakan biaya ongkos kirim yang biasanya ditetapkan oleh penjual sesuai objek (berat, dimensi, tujuan pemesanan). Jadi pembeli akan mentransfer sejumlah uang (harga ditambah ongkos kirim). Namun dibeberapa provider online, apabila provider mampu menekan dan mensiasati biaya pengiriman atau bahkan nol (bebas ongkos kirim). Inilah mengapa promo free ongkos kirim menjadi daya tarik bagi pembeli yang biasa melakukan pembelian secara online. Biasanya free ongkos kirim diberikan pada waktu dan ketentuan tertentu.

Pemasaran dalam perspektif syariah haruslah bersandar pada aturan-aturan yang telah ditetapkan dalam Al-Quran dan hadits. Kegiatan promosi mestilah transparan (terbuka) menjelaskan apa yang menjadi kelebihan dan kekurangan suatu produk dan jasa, promosi tersebut benar adanya dan informasi tersebut sesuai dengan yang dibutuhkan konsumen (Agustin, 2017:102). 
d. Tempat (Place)

Merupakan keputusan menegenai dimana lokasi usaha, bermarkas, dan sarana yang digunakan untuk memasarkan produk dan jasanya. Tempat meliputi pertimbangan bagaimana produk bisa sampai ke konsumen. Bagaimana suatu produk bisa diakses oleh konsumen dalam kondisi yang aman dan nyaman, strategis. Penting menetapkan dan mengembangkan saluran distribusi yang efisien dan pemilihan saluran distribusi yang tepat sehingga akan menimbulkan kesan yang istimewa dan tidak mudah dilupakan bagi konsumen atau pelanggannya (Agustin, 2017:103).

Dalam hal jual beli online maka tempat menjadi tidak begitu penting, maka yang menjadi penting adalah kemudahan dalam mengakses situs jual beli tersebut, memiliki variasi akun (keterhubungan/singkronisasi) media sosial, adanya layanan COD (cash on delivery), yaitu pertemuan kedua pihak untuk mengecek kondisi barang yang dipesan serta bisa juga melakukan pembayaran langsung, memiliki ketersediaan produk yang lengkap sehingga tidak memerlukan waktu yang lama dalam proses pemesanan dan pembelian. Dalam menentukan tempat perlu mempertimbangkan kemudahan akses menuju lokasi, visibilitas artinya mudah ditemukan lokasinya, adanya sarana parkir yang memadai, aman dan nyaman.

Rasulullah juga meminta penjual untuk tidak menyembunyikan barang apapun kepada konsumen untuk tujuan penimbunan. Rasulullah melarang menjual sesuatu barang yang tidak ada, tidak diperbolehkan untuk pergi ke pembeli lain kecuali negosiasi dengan pembeli pertama gagal. Rasulullah mengajarkan umat Islam memprioritaskan konsumen yang pertama negosiasi dalam rangka memenuhi dan menghormati semua konsumen (Agustin, 2017:105)

e. Orang (People)

Orang merupakan manusia yang bekerja di lingungan suatu organisasi., berpotensi sebagai penggerak organisasi dalam mewujudkan eksistensinya, serta maset berfungsi sebagai modal dalam organisasi bisnis. Pentingnya karyawan dalam suatu organisasi karena merekalah penggerak kegiatan tersebut sekalipun memiliki teknologi canggih (Agustin, 2017:51).

Karena orang merupakan penggerak bisnis, maka harus mempunyai karakteristik atau sifat-sifat dari shifatul anbiya'. Sifat itu antara lain akidah (taat pada Allah), shiddiq (benar), fathanah (cerdas), amanah (jujur/terpercaya), dan tabligh (komunikatif). Dengan sifat-sifat ini seseorang akan bekerja secara professional, artinya memiliki sifat kejujuran dan keahlian. Menempatkan seseorang berdasarkan keahliannya adalah tindakan yang tepat. Keterampilan atau keahlian biasanya diperoleh dari pengalaman, pendidikan, dan pelatihan dalam pekerjaan (Agustin, 2017:51).

Dalam hal jual beli online, pelayanan menjadi faktor penting, karena itu karyawan harus memiliki kriteria sebagai berikut transparan dalam memberikan informasi (informative), kesesuaian informasi dengan kebutuhan konsumen, empati berarti ramah, memahami konsumen, cepat tanggap, jaminan (assurance) artinya 
memiliki keahlian, skill, berintegritas, serta penampilan yang bersih dan rapi.

f. Proses (Process)

Berkaitan dengan bagaimana produk diproduksi dan disampaikan pada pelanggan, bagaimana layanan, kemudahan akses yang didapat pelanggan dari suatu perusahaan (Hudan dan et.al, 2017:18).

Dalam pembelian secara online proses meliputi variasi pembayaran, kemudahan proses pemesanan, dan kejelasan mekanisme pembayaran. Variasi pembayaran yang dimaksud adalah memiliki variasi rekening untuk proses transfer dalam pembelian, sehingga konsumen yang memiliki rekening yang berbeda bank tidak dikenakan biaya tambahan. Kemudahan proses pemesanan seperti kecepatan dalam merespon dan tepat dalam menangani kebutuhan konsumen. Kejelasan mekanisme pembayaran berarti rangkaian proses dari awal pembayaran hingga barng tersebut dikirim ada prosedur yang jelas.

g. Bukti Fisik (Physical Evidence)

Merupakan kondisi fisik yang dapat dilihat secara kasat mata dan dirasakan konsumen. Biasanya berbentuk toko atau bangunan, peralatan dan fasilitias yang tersedia, sarana serta bentuk pelayanan yang tidak dapat dipisahkan dari jasa dan produk itu sendiri. Dalam pembelian secara online yang menjadi bukti fisik adalah kemasan (Packaging), jasa cek resi, dan ketentuan waktu pengiriman. Kemasan barang haruslah aman dan rapi sehingga terhindar dari kerusakan, terteranya alamat pengiriman dan informasi terkait pengiriman. Jasa cek resi dibutuhkan bagi konsumen yang ingin mengetahui lokasi barang secara terkini dan ini menjadi faktor yang membuat konsumen menjadi yakin. Batas pengiriman yang ditetapkan haruslah sesuai dengan ketentuan awal antara pembeli dan penjual.

Untuk memberikan rasa nyaman dan aman pada konsumen maka harus memperhatikan penentuan layout gedung ataupun layout ruangan seperti bentuk gedung, lokasi parkir luas dan aman, suasana lingkungan atau lokasi, tersedia sarana yang dibutuhkan seperti tempat sholat dan kamar mandi.

\section{Jual Beli Online}

Jual beli online dalam Islam diistilahkan dengan transaksi Salam. Adalah jual beli yang tidak dilihat zatnya, hanya ditentukan dengan sifat, barang itu ada di dalam (tanggungan) si penjual. Jual beli secara online diketahui dengan detail jenis, karakteristik, harga, jumlah, tata cara pembayaran, dan tempat pembayaran. Calon pembeli akan mendapat barang pada saat diperlukan nanti dengan harga yang sudah ditetapkan dan penjual mendapatkan dana di depan yang digunakan untuk mengadakan barang (Hidayat, 2011: 52).

Dalam hadits Abdullâh bin Abbâs Radhiyallahu anhu diriwayatkan:
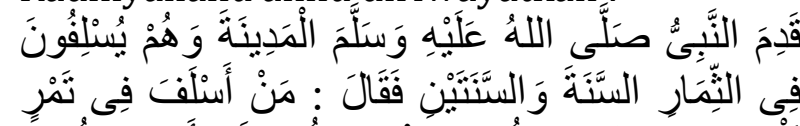

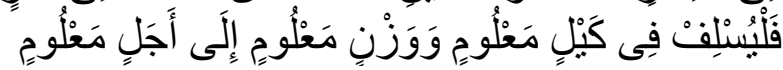

Artinya : "Ketika Nabi Shallallahu 'alaihi wa sallam tiba di kota Madinah, penduduk Madinah telah biasa memesan buah kurma dengan waktu satu dan dua tahun. maka beliau Shallallahu 'alaihi wa sallam bersabda, "Barangsiapa memesan kurma, maka hendaknya ia memesan dalam takaran, timbangan dan tempo yang jelas (diketahui oleh kedua 


\section{belah pihak)." (Muttafaqun 'alaih).}

Dalam transaksi jual beli online ada beberapa ketentuan yang harus dipenuhi agar tidak terjadi hal-hal yang tidak diinginkan oleh kedua belah pihak adalah hal-hal berikut :

a. dilakukan pada jenis komoditi yang jelas;

b. Kriteria/ciri-ciri komoditinya jelas;

c. Ukuran (takaran/ timbangan) komoditinya jelas;

d. Jatuh temponya jelas;

e. Jumlah uang (alat bayarnya) jelas; dan;

f. Disebutkan nama/alamat penyerahan komoditi jika untuk mengangkut memindahkan komoditinya memerlukan biaya dan terdapat kesulitan padanya (Al-Khasyt, 2011: 386).

Situs jual beli online yang ada di Indonesia diklasifikasikan lima model bisnis, pertama forum online (e-commerce) dan situs baris popular di Indonesia seperti OLX, Kaskus, dan Berniaga, kedua situs marketplace C2C (Consumers to Consumers) seperti Tokopedia, Bukalapak, Lamido Indonesia, Blanja, dan Elevenia, ketiga model bisnis yang memberlakukan proses verifikasi yang ketat disebut shopping mall seperti Blibli, keempat situs yang mengusung konsep B2C (Business to Consumers) seperti Lazada Indonesia, Agoda, Zalora Indonesia, Tiket, dan yang kelima toko online di media sosial menggunakan situs media sosial (platform) seperti Facebook, Instagram, WhatsApp, Line dan lain-lain (http://id.technisia.com).

Metode dalam pembayaran jual beli online ada 2, transfer bank, merupakan kegiatan pemindahan saldo rekening dari pembeli kepada penjual dengan nilai sesuai dengan kesepakatan kedua belah pihak. Yang kedua COD (Cash on Delivery) adalah pembayaran di lokasi yang telah disepakati penjual dan pembeli sekaligus melakukan pengecekan brang, serta konsumen memutuskan apakah membeli barang tersebut atau tidak. (Prasetio, 2012: 32).

\section{Jual Beli Offline}

Toko offline nampak secara kasat mata, dimana calon konsumen bisa mengetahui, nampak kondisi dan objek barang atau jasa yang diinginkan dan dibutuhkan. Pembayaran juga dapat dilakukan pada saat itu juga tanpa melalui perantara. Mendirikan toko offline juga harus mempersiapkan lokasi yang strategis sehingga memudahkan pelanggan untuk datang. Selain itu, Pelanggan tidak harus dikenai biaya tambahan utuk ongkos kirim karena mereka bisa langsung membayar di tempat. Dari segi barang atau jasa yang ditawarkan dapat terlihat secara nyata sehingga meminimalkan kesalahan pemilihan barang dan secara otomatis tingkat kepercayaan pembeli cenderung tinggi. Toko offline (konvensional) biasanya memiliki variasi produk yang banyak dan lengkap karena stok perjenis produk lebih sedikit. Tidak terhambat oleh hal-hal yang berhubungan dengan teknologi berbasis koneksi internet yang sedang terputus. Dari segi jangkauan pasarnya terbatas, hanya dapat memasarkan produk atau jasanya disekitar tokonya saja. Toko offline memerlukan biaya dan waktu yang lebih, dalam hal ini termasuk lokasi yang strategis, mengisi persediaan barang, menggaji karyawan, dan mempromosikan toko untuk menarik minat pasar, dan biaya pengembangan usaha (sumber internet: http://fashionkieshop.blogspot.co.id).

\section{Hijab}

Hijab adalah sesuatu yang menutupi atau menghalangi dirinya baik tembok atau sekat. Namun yang dimaksud hijab di sini adalah kain penutup aurat atau yang diistilahkan dengan jilbab (Iskandar, 2013:88). Jilbab berasal dari Bahasa arab jalaba, yang berarti menghimpun atau membawa, secara etimologis artinya kain 
penutup kepala, dada, punggung bahkan seluruh tubuh hingga telapak kaki. Sedangkan yang dimaksud jilbab dikalangan wanita Indonesia adalah kerudung (khimar) (Firdaus, 2013:18). Dalam pembahasan ini yang dimaksud hijab adalah kerudung (khimar).

Kerudung dalam bahasa arab berarti khimar. Khimar adalah kain penutup yang digunakan wanita untuk menutupi kepala hingga ke dada. (Sufyan, 2013: 38). Jadi istilah jilbab atau hijab lebih bersifat umum dibandingkan kerudung.

Jilbab yang wajib dikenakan oleh setiap muslimah, haruslah memenuhi 8 syarat (Sufyan, 2013: 38) yaitu menutupi seluruh tubuh (selain wajah dan telapak tangan), tidak merupakan perhiasan yang berlebihan dengan sendirinya, berbahan tebal dan tidak tipis (tembus pandang), longgar dan tidak sempit (ketat), tidak diberi wangi-wangian yang belebih-lebihan, tidak menyerupai pakaian lelaki, tidak menyerupai pakaian khas wanita kafir, tidak menyerupai pakaian syuhrah, syuhrah berarti pakaian yang menarik perhatian, dianggap aneh, dan mengundang tawa (Sufyan, 2013: 38).

\section{METODE}

Jenis Penelitian ini komparatif yaitu untuk mengetahui perbedaan di antara dua kelompok data (variabel) atau lebih (Hasan, 2010:116). Penelitian ini bertujuan untuk mengetahui komparasi (perbandingan) strategi pemasaran dalam transaksi jual beli online dan offline pada hijab (Studi Kasus: Mahasiswi Universitas Islam Riau). Lokasi Penelitian di Jl. Kaharudin Nasution No. 133 Perhentian Marpoyan, PekanbaruRiau, tepatnya Universitas Islam Riau. Dilakukan pada Desember 2018-Maret 2019.

Populasi adalah Seluruh Mahasiswi Universitas Islam Riau Tahun Akademik
2018/2019 sebanyak 12.978. dalam penentuan jumlah sampel menggunakan rumus Slovin sebanyak 99 orang. Teknik Pengambilan sampel menggunakan Proportioned Stratified random sampling (acak dan berstrata secara proporsional). Subjek penelitian mahasiswi Universitas Islam Riau dan objek penelitian strategi pemasaran dalam transaksi jual beli online dan offline pada hijab (Mahasiswi Universitas Islam Riau). Sumber data primer (hasil angket) dan sekunder (data jumlah mahasiswi). Teknik pengumpulan melalui angket dan dokumentasi. Teknik pengolahan data meliputi penyuntingan (editing), pengkodean (coding), pentabulasian (tabulating). Analisis data secara kuantitatif menggunakan Microsoft Excel dan SPSS 23. Uji instrumen meliputi uji validitas (keabsahan) dan uji reliabilitas (konsisten).

Uji asumsi klasik uji normalitas dan homogenitas. Uji normalitas dilakukan untuk mengetahui apakah nilai residual berdistribusi normal atau tidak, dalam uji normalitas jika nilai signifikansi $>0,05$, maka nilai residual berdistribusi normal, begitu sebaliknya. Sedangkan uji homogenitas adalah pengujian mengenai sama tidaknya variansi-variansi dua buah distribusi atau lebih. Dasar pengambilan keputusan dalam uji homogenitas adalah apabila nilai signifikansi $>0,05$ maka distribusi data bersifat homogen. Selanjutnya pengujian hipotesis dengan menggunakan Program SPSS 23 dengan analisis paired t-test (Uji $\mathrm{t}$ dua sampel berpasangan) dengan probabilitas $5 \% \quad(0,05)$. Menentukan kriteria pengujian dengan membandingkan $t_{\text {hitung }}>t_{\text {tabel }}$ atau $-t_{\text {hitung }}<-t$ tabel. $\mathrm{H}_{\mathrm{a}}$ diterima (ada perbedaan strategi pemasaran dalam jual beli online dan offline pada hijab (Studi Kasus: Mahasiswi Universitas Islam Riau). Berdasarkan nilai probabilitas (tingkat 
kesalahan) atau 0,05 (5\%) yaitu Nilai sig. < 0,025 maka $\mathrm{H}_{\mathrm{a}}$ diterima.

\section{PEMBAHASAN}

Strategi pemasaran penting dalam tercapainya pemenuhan kebutuhan manusia di dunia dengan memperhatikan kebahagiaan (falah) di akhirat. Konsumen tidak hanya memperhatikan kegunaan (utility) suatu barang dan jasa, namun bagaimana seharusnya menurut nilai-nilai ajaran Islam.

Ada beberapa faktor strategi pemasaran dalam jual beli online $\left(\mathrm{X}_{1}\right)$ dan offline $\left(\mathrm{X}_{2}\right)$ dalam produk hijab dari segi produk, harga, promosi, tempat (saluran distribusi), orang (karyawan), proses dan bukti fisik. Hasil penelitian strategi pemasaran dalam pembelian hijab berdasarkan faktor produk sebesar 79,5\% ( $\left.\mathrm{X}_{1}\right)$ dan 84,5\% (X $\left.\mathrm{X}_{2}\right)$. Ini berarti dalam segi produk hijab konsumen lebih merasa puas pada jual beli offline karena kecilnya resiko terhindar dari kesalahan barang, kualitas sesuai harapan konsumen, dan sesuai dengan spesifikasi.

Pada faktor harga meliputi strategi pemasaran dalam pembelian hijab online $\left(\mathrm{X}_{1}\right)$ sebesar $81,7 \%$ sedangkan strategi pemasaran dalam pembelian hijab offline $\left(\mathrm{X}_{2}\right)$ sebesar $80,7 \%$. Hal ini menunjukkan harga hijab online lebih murah, terjangkau dan bersaing. Pada faktor promosi besar strategi pemasaran dalam pembelian hijab online $\left(\mathrm{X}_{1}\right) \quad 77,8 \%$ sedangkan strategi pemasaran dalam pembelian hijab offline $\left(\mathrm{X}_{2}\right)$ sebesar 77,3\%. Artinya berdasarkan faktor promosi tingkat strategi pemasaran dalam produk hijab pada jual beli online line $\left(\mathrm{X}_{1}\right)$ dan offline $\left(\mathrm{X}_{2}\right)$ hampir sama.

Selanjutnya dari segi tempat, strategi pemasaran dalam produk hijab pada jual beli online $\left(\mathrm{X}_{1}\right)$ sebesar $78,9 \%$, sedangkan strategi pemasaran dalam produk hijab pada jual beli offline $\left(\mathrm{X}_{2}\right)$ sebesar $79,5 \%$. Hal ini juga tidak jauh berbeda. Strategi pemasaran berdasarkan faktor orang dalam produk hijab pada jual beli online $\left(\mathrm{X}_{1}\right)$ sebesar 78,3\%, sedangkan pada jual beli offline $\left(\mathrm{X}_{2}\right)$ sebesar $81,8 \%$. Hal ini berarti karyawan dalam jual beli hijab offline $\left(\mathrm{X}_{2}\right)$ lebih transparan, ramah, perhatian serta memahami kebutuhan konsumen.

Pada faktor proses nilai yang lebih besar tingkat kepuasannya adalah jual beli hijab offline $\left(\mathrm{X}_{2}\right)$ sebesar $81,8 \%$ dan strategi pemasaran dalam produk hijab pada jual beli online $\left(\mathrm{X}_{1}\right)$ sebesar 80,2\%. Berdasarkan faktor bukti fisik responden (Mahasiswi Universitas Islam Riau) menyatakan lebih puas terhadap jual beli offline $\left(\mathrm{X}_{2}\right)$ dalam produk hijab sebesar 80,6\% dibandingkan pada jual beli online $\left(\mathrm{X}_{1}\right)$ dalam produk hijab sebesar $78,3 \%$.

Dari semua faktor produk, harga, promo, tempat, orang, proses dan bukti fisik maka lebih besar strategi pemasaran (Mahasiswi Universitas Islam Riau) dalam transaksi jual beli offline $\left(\mathrm{X}_{2}\right)$ pada Kerudung sebesar 81\%. Sedangkan strategi pemasaran (Mahasiswi Universitas Islam Riau) dalam transaksi jual beli online (X1) pada Kerudung sebesar 79,4\%.

Berdasarkan hasil uji Perbandingan (Paired T-test) diketahui nilai signifikansi (2-tailed) sebesar 0,008 $<0,05$ (nilai probabilitas).

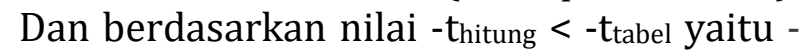
2,692 < -0.196, maka ini membuktikan hipotesis $\mathrm{H}_{\mathrm{a}}$ diterima, yakni Terdapat perbedaan strategi pemasaran dalam jual beli online dan offline pada Kerudung muslimah (Mahasiswi Universitas Islam Riau).

\section{SIMPULAN}

Berdasarkan uji perbandingan (komparatif) strategi pemasaran dalam transaksi jual beli online dan offline pada hijab (Studi Kasus: Mahasiswi Universitas Islam Riau) adalah : 
1. Terdapat perbedaan strategi pemasaran dalam transaksi jual beli online dan offline pada Hijab (Studi Kasus: Mahasiswi Universitas Islam Riau). Strategi pemasaran dalam transaksi jual beli offline $\left(\mathrm{X}_{2}\right)$ pada Hijab (Studi Kasus: Mahasiswi Universitas Islam Riau) lebih unggul dibandingkan strategi pemasaran dalam transaksi online $\left(\mathrm{X}_{1}\right)$ pada hijab (Studi Kasus: Mahasiswi Universitas Islam Riau) atau $\mathrm{X}_{2}>\mathrm{X}_{1}$.

\section{DAFTAR RUJUKAN}

Al Arif, M. Nur Rianto dan Euis Amalia, 2010, Teori Mikroekonomi (suatu perbandingan ekonomi islam dan ekonom konvensional), Kencana, Jakarta.

Agustin, Hamdi, 2017, Studi Kelayakan Bisnis Syariah, Rajawali Pers, Depok.

Al-Khasyt, Muhammad Ustman, 2011, Fiqh Wanita 4 Mazhab, Khazanah Intelektual, Bandung.

Firdaus, Iqro', 2013, Bismillah Aku berjilbab, Diva Press, Yogyakarta.

Ghazaly, Abdul Rahman dkk, 2010, Fiqh Muamalat, Kencana, Jakarta.

Hasan, Iqbal, 2010, Analisis Data Penelitian dengan Statistik, PT. Bumi Aksara, Jakarta.

Hidayat, Enang, 2011, Fiqh Jual Beli, PT Remaja Rosdakarya, Bandung.

Huda, Nurul dkk, 2017, Pemasaran Syariah Teori dan Aplikasi, Kencana, Depok

Iskandar, Arief, 2013, Jilbab Syar'i, Khilafah Press, Jakarta.

Kotler, Philip dan Keller, Kevin Lane, 2008, Manajemen Pemasaran. Jilid I. Edisi ke 13, Erlangga, Jakarta.

Prasetio, Adhi, 2012, Smart Guide Jualan Online, TransMedia, Jakarta.
Rambat, Lupiyoadi, dan A. Hamdani, 2008, Manajemen Pemasaran Jasa, Edisi Kedua, Salemba Empat, Jakarta.

Sanusi, Anwar, 2016, Metodologi Penelitian Bisnis, , Salemba Empat, Jakarta.

Setiadi, Nugroho J, 2013, Perilaku Konsumen, Kencana, Jakarta.

Siregar, Syofian, 2014, Statistik Parametrik untuk Penelitian Kuantitatif, Bumi Aksara, Jakarta

Sufyan, 2013, Samudera Hikmah di Balik Jilbab Muslimah. Pustaka Al Inabah, Bandung.

Sugiyono, 2013, Metode Penelitian Kuantitatif Kualitatif dan R\&D. Bandung, Alfabeta.

Tjiptono, Fandy, 2008, Strategi Pemasaran, Edisi 3, CV. Andi, Yogyakarta 